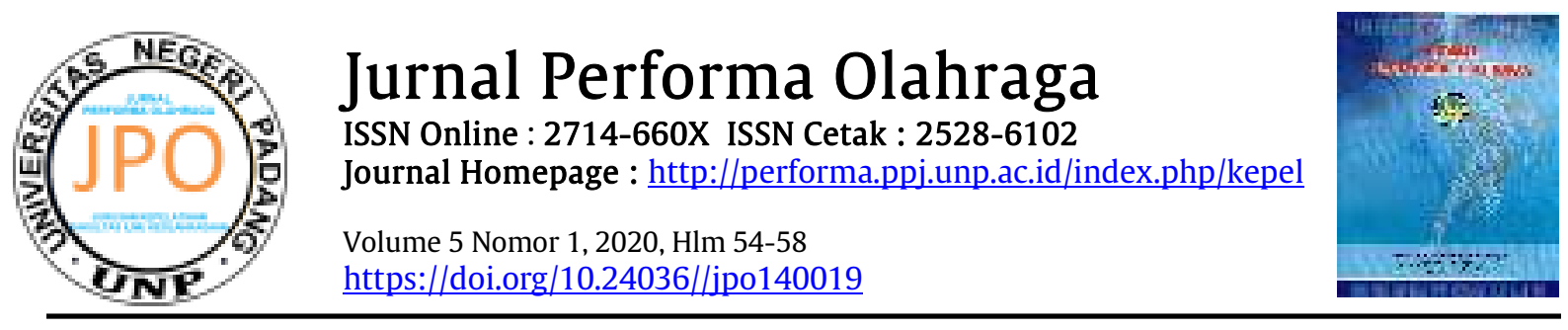

\title{
Perilaku Masyarakat terhadap Anak Berkebutuhan Khusus Sekolah Luar Biasa Perwari Padang
}

\author{
Saskia Putri Rahayu ${ }^{1}$, Eddy Marheni ${ }^{2}$ \\ Fakultas Ilmu Keolahragaan, Universitas Negeri Padang, Indonesia
}

\section{Informasi Artikel}

Diterima 08-06-2020

Direvisi Aug 10-06-2020

Dipublikasikan 17-06-2020

\section{Keyword:}

Children with Special Needs; Bullying; Extraordinary school

\begin{abstract}
Community behavior towards children with special needs of Perwari Padang SLB in Ulak Karang Selatan is very important for research. Because Ulak Karang Selatan is one of the villages closest to the city center which is the location of the school. Because they have the right to grow and develop their creativity. This type of research is quantitative research with a descriptive approach. The study was conducted from 10 December 2019 to 20 January 2020 in SLB Perwari Padang and Ulak Karang Selatan Village. This research involved 6 ABK Parents, 4 Ulak Karang Selatan Community, 4 Perwari Padang SLB teachers, 1 Canteen Guard, and 1 psychology graduate and had long been in the world of children. The techniques used in this research are data collection, data reduction, display | data, data verification and triangulation. The findings of the study indicate the level of public concern for ABK in southern Ulak Karang is still low. Evidenced by the existence of physical and verbal bullying behavior towards $A B K$ which affects the psychological condition. The method of parenting education is still quite rigid and causes children to be unable to socialize.
\end{abstract}

(c) 2020 The Authors. Published by Universitas Negeri Padang.

This is an open access article under the CC BY-NC-SA license https://creativecommons.org/licenses/by-nc-sa/4.0

\section{Penulis Korespondensi:}

Saskia Putri Rahayu

Universitas Negeri Padang

E-mail: saskaputrirahayu@gmail.com

\section{PENDAHULUAN}

Fenomena bullying adalah sebuah hal yang sangat perlu dibahas dan menjadi hal yang sangat penting untuk diteliti.Bullying merupakan sebuah tindakan agresi yang dapat mengakibatkan korban bullying, pelaku bullying, ataupun mereka yang masuk kedalam kelompok bullying tersebut menderita depresi dan bahkan tinggi kemungkinannya untuk melakukan bunuh diri serta mengalami gangguan pada kesehatan psikologisnya (Hinduja dan W. Pacthin,2010; M. Kowalski \& P.Limber, 2012; Gradinger, dkk, 2009). Marheni (2012 :5) mengelompokkan bentukbentuk kekerasan dalam beberapa macam diantaranya kekerasan fisik, kekerasan psikis atau mental dan kekerasan verbal. Ketiga bentuk kekerasan tersebut memberikan derita kejiwaan dan trauma yang sangat berat bagi anak berkebutuhan khusus.

Dampak negtaif yang diakibatkan oleh perilaku bullying menjadi landasan pentingnya penulis meneliti perilaku bullying terhadap anak berkebutuhan khusus.Anak-anak korban bullying bisa mengalami depresi dan gangguan kecemasan, Perasaan sedih dan kesepian bisa meningkat akibat tindakan bullying tersebut.Mengalami perubahan pola tidur dan makan serta bisa kehilangan minat pada aktivitas yang dulu pernah sangat disukai.Selain itu korban dapat mengalami psikomatis ketika akan bersosialisasi dengan anak-anak yang normal lainnya, merasa 
tidak berharga, merasa terasingkan, depresi hingga sampai kepada tindakan bunuh diri (Arya, $2018: 27)$.

Mufidah (2008) berpendapat kekerasan yang dilakukan dengan menggunakan kekuatan fisik atau non fisik secara sengaja hanya untuk menimbulkan rasa derita kepada pihak yang menjadi objek kekerasan.Dampak tersebut bisa berlangsung hingga mereka dewasa.Bahkan tindakan bullying akan sangat besar dampaknya apabila dialami oleh mereka yang memiliki kecacatan mental atau berkebutuhan khusus apalagi kepada anak-anak.

Anak berkebutuhan khusus adalah mereka yang memiliki keterbelakangan mental dan kekurangan dari beberapa hal yang dimiliki oleh anak normal lainnya.Kekurangan dan keterbelakangan yang mereka miliki menjadi alasan mengapa mereka sering menjadi korban bullying di tengah lingkungan masyarakat.hal tersebut bukan berarti siapa saja boleh untuk merendahkan dan menertawakan mereka.

Pendidikan anak berkebutuhan khusus di Indonesia sangat diperhatikan oleh pemerintah.Adanya UU pendidikan yang mengatur khusus tentang hak anak berkebutuhan khusus dalam memperoleh pendidikan menjadi bukti kepedulian pemerintah terhadap mereka.Lingkungan pendidikan memang sudah mengatur hal tersebut. Namun, kita tidak bisa memprediksi lingkungan masyarakatnya bagaimana.Tujuan adanya sekolah khusus ini adalah memberi kebebasan bagi anak berkebutuhan khusus untuk mengembangkan bakat dan mendapatkan hak yang sama untuk berkreasi seperti anak normal biasanya. Namun ketika mereka mengalamitindakanbullyingmaka besar kemungkinan akan membunuh perkembangan kreativitas mereka.

Data statistik Kementerian Pendidikan dan Kebudayaan Pusat Data dan Statistik tahun 2017 menyebutkan jumlah sekolah luar biasa (SLB) di Indonesia yaitu 10.774 SLB negeri dan 17.217 SLB swasta. Sedangkan Sumatera Barat sendiri memiliki 115 SLB negeri dan swasta. Salah satu sekolah luar biasa yang ada di Kota Padang adalah SLB Perwari Padang. Jumlah tersebut membuktikan bahwa pendidikan anak berkebutuhan khusus tidak kalah penting dari pendidikan anak normal lainnya.Akan tetapi, Jumlah itu bertolak belakang dengan realitanya dari segi kualitas.

Berdasarkan hasil survei dan wawancara awal yang penulis lakukan di Sekolah Luar Biasa Perwari Padang dengan beberapa guru dan wali murid yang saat itu berada di sekolah, diperoleh gambaran terhadap indikasi adanya perilaku bullying yang dialami siswa. Hal ini terlihat dari fenomena-fenomena yang ditemui diantaranya:

1) Beberapa peserta didik ketika bertemu dengan orang yang baru dikenalmenunjukkan sikap malu dan tidak percaya diri dengan keadaan dirinya sendiri, Seperti merunduk, tidak mau bicara, dan melihat orang hanya dari kejauahan saja.

2) Beberapa orangtua peserta didik merasa tidak bersalah ketika mememarahi anaknya didepan teman sebaya mereka.

3) Beberapa peserta didik menunjukkan sikap takut yang berlebihan ketika dimarahi oleh guru, seperti menutup mata, menutup telinga dan bahkan hampir menangis.

Berdasarkan masalah yang diperoleh, penting adanya pembahasan tentang perilaku masyarakat terhadapanak berkebutuhan khusus, maka menimbul kankeninginan penulis untuk meneliti lebih lanjut tentang Perilaku masyarakat terhadap anak berkebutuhan khusus di SLB Perwari Padang.

\section{METODOLOGI}

Jenis penelitian ini adalah penelitian kualitatif. Tujuannya adalah untuk memahami fenomena tentang apa yang dialami oleh subyek penelitian mengenai perilaku masyarakat terhadap anak berkebutuhan khusus sekolah luarbiasa perwari padang di kelurahan ulak karang selatan. Metode penelitian kualitatif adalah metode yang digunakan untuk meneliti saat kondisi obyek alamiah dimana peneliti sebagai instrumen kunci. teknik pengumpulan data dilakukan dengan triangulasi, analisis data bersifat induktif, dan hasil penelitian menekankan pada makna dari pada generalisasi. Penelitian kualitatif yang digunakan pada penelitian ini dimaksudkan untuk memperoleh informasi mengenai perilaku masyarakat yang tergolong kedalam tindakan 
bullying verbal dan fisik terhadap anak berkebutuhan khusus SLB Perwari Padang di ulak karang selatan.

\section{HASIL DAN PEMBAHASAN}

\section{Hasil Penelitian}

Penelitian ini dilakukan di sekolah luar biasa perwari padang (SLB) yang merupakan salah satu sekolah swasta yang ada di Kota Padang. pengambilan sampel dalam penelitian ini menggunakan purposive sampling yaitu peneliti mengambil sampel berdasarkan jumlah siswa terbanyak yang tinggal di salah satu kelurahan. Daftar alamat tempat tinggal siswa diperoleh dari tata usaha (TU) SLB Perwari Padang.Rekapitulasi alamat tempat tinggal siswa dapat dilihat pada tabel dibawah ini.

Tabel 1. Rekapitulasi Alamat Tempat Tinggal Siswa SLB Perwari Padang Tahun ajaran 2019/2020

\begin{tabular}{|c|c|c|c|}
\hline No. & Kecamatan & Kelurahan & Jumlah siswa \\
\hline \multirow{7}{*}{1.} & \multirow{7}{*}{ Kec. Koto Tangah } & Bungo Pasang & 3 \\
\hline & & Batang Kabung & 2 \\
\hline & & Lubuk Buaya & 1 \\
\hline & & Batipuh Panjang & 1 \\
\hline & & Dadok Tunggul Hitam & 2 \\
\hline & & Lubuk Minturun & 3 \\
\hline & & Parupuk Tabing & 4 \\
\hline \multirow{4}{*}{2.} & \multirow{4}{*}{ Kec. Padang Barat } & Purus & 5 \\
\hline & & Olo & 1 \\
\hline & & Lolong & 1 \\
\hline & & Rimbo Kaluang & 2 \\
\hline \multirow{4}{*}{3.} & \multirow{4}{*}{ Kec. Padang Utara } & Lolong Belanti & 1 \\
\hline & & Ulak Karang Selatan & 6 \\
\hline & & Air Tawar & 3 \\
\hline & & Ulak Karang Utara & 5 \\
\hline 4. & Kec. Padang Selatan & Batang Arau & 1 \\
\hline \multirow[t]{2}{*}{5.} & Kec. Nanggalo & Surau Gadang & 1 \\
\hline & \multicolumn{2}{|c|}{ JUMLAH } & 43 \\
\hline
\end{tabular}

Sumber: TU SLB Perwari Padang

Berdasarkan rekapitulasi tersebut Kelurahan Ulak Karang Selatan merupakan kelurahan yang siswa SLB Perwari Padang paling banyak berasal atau bertempat tinggal disana.siswa-siswa yang bertempat tinggal di Ulak Karang Selatan diantaranya adalah:

Tabel 2. Rekapitulasi Siswa yang Bertempat Tinggal di Ulak Karang Selatan

\begin{tabular}{|c|l|c|l|}
\hline No. & \multicolumn{1}{|c|}{ Nama } & $\begin{array}{c}\text { Jenjang Pendidikan/ } \\
\text { Kelas }\end{array}$ & \multicolumn{1}{|c|}{ Alamat } \\
\hline 1. & Arief Azafi & SMPLB/7 C & Jl. Bahari No 27 A \\
\hline 2. & $\begin{array}{l}\text { Rahma Purnama } \\
\text { Sari }\end{array}$ & SMALB/ 12 C & $\begin{array}{l}\text { Jl. Pekanbaru No. 30 Ulak Karang } \\
\text { Selatan }\end{array}$ \\
\hline 3. & Tania Safitri & SDLB/6 B & Jl. Hiu Ii \\
\hline 4. & Reni Baharudin & SMALB/12 C & Jl. Hiu No.30 \\
\hline 5. & Nadia Putri & SMPLB/7 C & Jl Bahari No. 47 \\
\hline 6. & Nursadrina & SMPLB/7 C & Jl. Bahari No. 32 D \\
\hline
\end{tabular}

Sumber: TU SLB Perwari Padang

Keterangan:

B : kode untuk kelas Tunarungu 
C: kode untuk kelas Tunagrahita

Data yang peneliti peroleh dari hasil penelitian menunjukkan adanya perilaku atau tindakan bullying yang dialami oleh ABK SLB Perwari Padang.jenis bullying yang dilakukan yaitu bullying verbal dan bullying fisik.Caranya bermacam-macam ada yang dengan mentertawakan/ mengejek, mencubit, mengucilkan dan melakukan perampasan atau pemalakan.

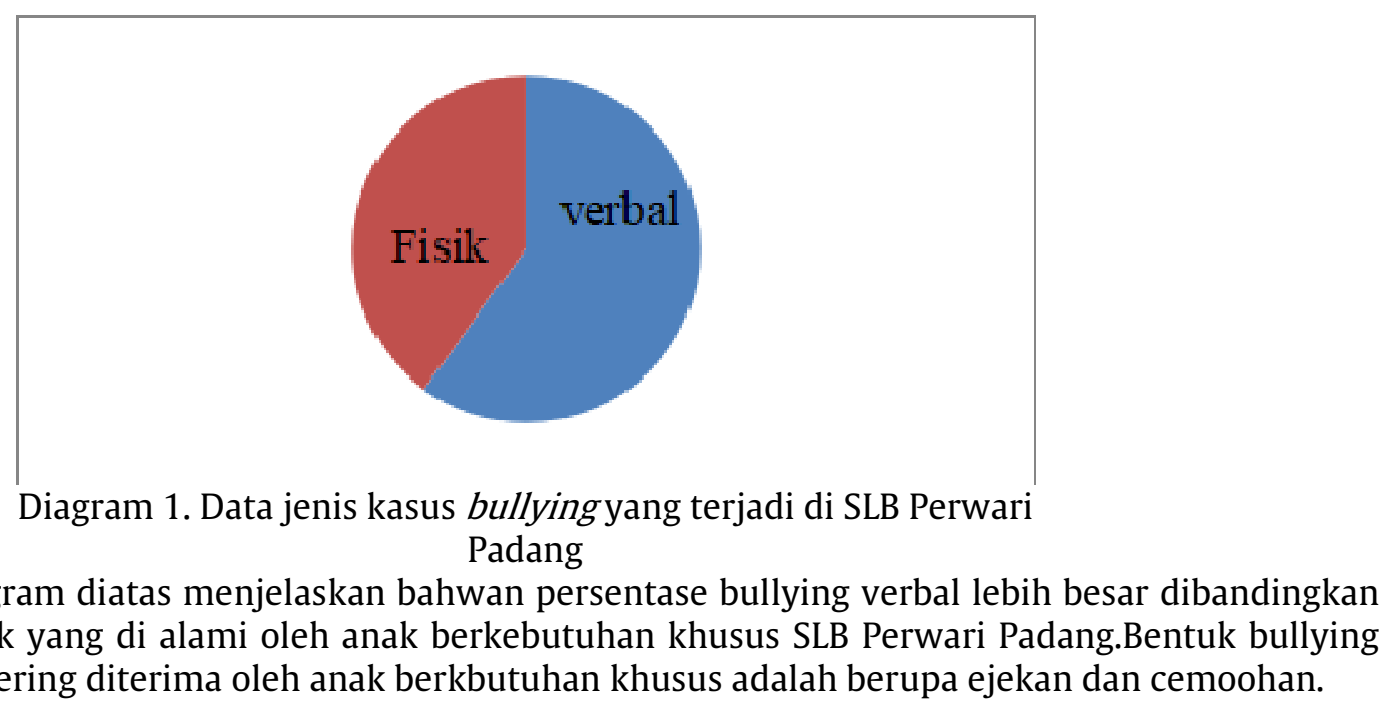

Temuan penelitian, beberapa orangtua menganggap anaknya tidak bisa dilepas sendirian untuk bermain keluar rumah. Selain rasa takut anak akan berbuat jahat kepada orang lain, mereka juga merasa belum siap diri untuk menerima keadaan anak. Padahal lingkungan masyarakat adalah wadah pendidikan yang sangat bagus dan cepat bagi anak untuk mengenal dan menggali potensi diri mereka.Karena keluarga dan masyarakat adalah gerbang pertama untuk anak dalam mengekpresikan perasaannya.Selaras dengan pendapat Agustin, dkk (2015:8) yang menyebutkan keluarga dan lingkungan masyarakat merupakan tempat untuk membentuk moral dan tingkah laku anak pada masa pertumbuhannya serta lingkungan masyarakat menjadi wadah pertama dalam menjawab semua pertanyaan yang ingin mereka ketahui.

\section{Pembahasan}

Peneliti telah memperoleh informaasi dari hasil wawancara, observasi dan studi dokumentasi dalam penelitian mengenai perilaku masyarakat terhadap anak berkebutuhan khusus.Hasil dari deskripsi kualitatif yang dilakukan oleh peneliti menunjukkan bahwa setiap subjek/informan yang diwawancarai, peneliti selalu memperoleh pemahaman ataupun pandangan yang berbeda mengenai perilaku bullying terhadap anak berkebutuhan khusus SLB Perwari Padang di Kelurahan Ulak Karang selatan.Pemahaman dan pandangan yang dimaksud adalah cara subjek menanggapi perilaku bullying yang diperoleh berbeda-beda sesuai dengan jenis kelaminnya. Misalnya anak berkebutuhan khusus laki-laki berbeda cara menanggapi perilaku bullyingnya dengan anak berkebutuhan khusus yang perempuan.Pandangan mengenai perilaku bullying terhadap anak berkebutuhan khusus memiliki jawaban yang berbeda-beda.Seperti yang telah dibahas pada temuan wawancara, peneliti menemukan adanya perilaku bullying terhadap anak berkebutuhan khusus.Diantaranya adalah melabel, mengejek, membeda-bedakan, mendorong dan melakukan pemalakkan.

Berdasarkan hasil penelitian yang peneliti telah lakukan, jelas bahwa apa yang dirasakan anak berkebutuhan khusus seperti AA, NP, dan TS merupakan bentuk tindakan bullying yang bersifat verbal dan fisik. Bentuk tindakan tersebut tentu menimbulkan respon dari anak berkebutuhan khusus.Cara masing-masing anak berkebutuhan khusus untuk merespon tindakan bullying yang mereka alami tidak sama. Besar atau kecilnya dampak negatif yang ditimbulkan dari bullying terhadap emosi dan jenis intimidasi tergantung dari tingkatan sekolahnya dan jenis kelaminnya serta bentuk bullyingnya. Sikap AA ketika di bully lebih agresif, namun dia mau mengakui dan menceritaan kesalahan yang dilakukan kepada orangtua dengan caranya sendiri.Karena orangtua AA selalu mengajarkan untuk selalu jujur dan tidak boleh berbohong. 
Sedangkan TS seorang anak perempuan yang pada hakikatnya tidak suka kasar dan lebih memilih diam saat mendapat bully dari temannya. Pada umumnya mereka memang merespon dengan diam dan menangis, serta membiarkan hal tersebut berlalu.Diam tak berdaya serta tidak adanya pembelaan diri tentu membuat perilaku bullying tersebut berlangsung secara terum menerus.

Faktor penyebab terjadinya bullying di Ulak Karang Selatan dikarenakan kurangnya pemahaman orangtu, guru dan masyarakat tentang bullying dan dampaknya pada anak.Faktor lingkungan masyarakat yang tidak menciptakan rasa aman tentu juga menjadi penyebab terjadinya perilaku bullying.(Aristo, 2009) menyebutkan faktor terjadinya bullying terdiri dari keluarga, sekolah, faktor teman kelompok sebaya, kondisi lingkungan sosial, dan tayangan televisi dan media cetak.

Masyarakat Ulak Karang Selatan memperlakukan anak berkebutuhan khusus dengan cara yang berbeda-beda. Secara garis besar untuk bullying hanya dilakukan oleh teman-teman sebaya.Namun masyarakat disana juga tidak mempuyai program atau kegiatan khusus yang dilaksanakan untuk anak berkebutuhan khusus di ulak karang selatan.

\section{KESIMPULAN}

Terdapat perilaku bullying verbal terhadap anak berkebutuhan khusus di Ulak Karang Selatan.Seperti mengejek dan menertawakan dengan mengatakan bisu, bisu .Orangtua anak berkebutuhan khusus di Ulak Karang Selatan tidak mengetahui cara mendidik anak berkebutuhan khusus dengan tepat. karena latar belakang pendidikan yang tamatan SMA. Selain itu kepedulian masyarakat terhadap anak berkebutuhan khusus juga tergolong masih rendah.Kepada orangtua, hendaknya tidak berkata kasar ketika memberikan pengarahan ataupun nasehat kepada anak. Tidak selalu menyalahkan mereka ketika mereka berperilaku kasar kepada orang lain. Namun anak berkebutuhan khusus itu hanya perlu penegasan bukan kekerasan. Selain itu orangtua hendaknya memperbolehkan anak berkebutuhan khusus untuk bersosiallisasi dengan masyarakat dan teman-teman sebayanya agar bakat dan minat mereka dapat berkembang dengan baik.

\section{DAFTAR PUSTAKA}

HindujaSameer\& W. Patchin Justin. 2010. -Bullying, Cyberbullying, and Suicide. // Routledge, 14 (206-221).

M. Kowalski Robin\& P. Limber Susan. 2012. Psychological, Physical, and Academic Correlates of Cyber bullyingand Traditional Bullying. //Jurnal Adolescent Health, 53 (13-20).

GradingerPetra, dkk. 2009. Traditional Bullyingand CyberbullyingIdentification of Risk Groups for Adjustment Problems. // Journal of Psychology, 217 (4) 205- 2013.

Muhammad, M. (2009).-Aspek Perlindung-an Anak Dalam Tindak Kekerasan (bullying) Terhadap Siswa Korban Kekerasan Di Sekolah.// Jurnal Dinamika Hukum, 9(3) 20-29.

Agustin, dkk. 2015. Peran Keluarga Sangat Penting Dalam Pembentukan Karakter Anak.// Jurnal Sosial Humaniora, Vol VIII, nomor 1.

Ariesto, A. 2009.Pelaksanaan Program Antibullying Teacher Empowerment.Diakses 12 juli 2019.

Arya, Lutfi. 2018. Melawan Bullying: Menggagas Kurikulum Anti Bullying Di Sekolah. Mojokerto.Sepilar.

Marheni, Eddy, dkk.2012. - Bullying Vs Tawuran : Studi Tentang Kematangan Emosional Siswa SMK Kota Padang. //Universitas Negeri Padang 